\title{
MANAJEMEN RANTAI PASOK BERAS DI KECAMATAN KOTAMOBAGU SELATAN, KOTA KOTAMOBAGU
}

\author{
Gaby Yosefanny Merry Sepang \\ Juliana R. Mandei \\ Caroline B. D. Pakasi
}

\begin{abstract}
ABSRACT
This study aims to determine the rice supply chain management. Data retrieval is done is primary data and secondary data. Primary data were obtained through a list of questions that had been prepared, while secondary data obtained from relevant agencies to study the Agriculture Department Kotamobagu. The sampling method is done by snowball sampling, where the sample is obtained based on information from first responders then browse to the next respondent. Data presented in tables and descriptive analysis to describe the characteristics of respondents. The concept of measuring variables used is the procurement, planning and control, operations or production and delivery or distribution. These results indicate that the rice supply chain management in the District of South Kotamobagu starting from farmers in the form of grain and then distributed by the farmers to millers. Activities drying, milling and packaging is done by the rice mill, then sold to wholesalers and retailers or directly to the final consumer in the form of rice. The process of the activities in the implementation of supply chain management is divided into three main streams are managed properly, the flow of goods / products, financial flows and the flow of information so that the production of rice in each member of the supply chain is always available.
\end{abstract}

Keywords: management, supply chain, rice, South Kotamobagu Sub-district, Kotamobagu City

\begin{abstract}
ABSRTAK
Penelitian ini bertujuan untuk mengetahui manajemen rantai pasok beras. Pengambilan data yang dilakukan yaitu data primer dan data sekunder. Data primer diperoleh melalui daftar pertanyaan yang telah disiapkan, sedangkan data sekunder diperoleh dari instansi terkait dengan penelitian ini yakni Dinas Pertanian Kota Kotamobagu. Metode pengambilan sampel dilakukan dengan cara Snowball Sampling, dimana sampel diperoleh berdasarkan informasi dari responden pertama kemudian di telusuri ke responden berikutnya. Data disajikan dalam bentuk tabel dan dianalisis secara deskriptif untuk menggambarkan karakteristik responden. Konsep pengukuran variabel yang digunakan adalah pengadaan, perencanaan dan pengendalian, operasi atau produksi dan pengiriman atau distribusi. Hasil penelitian ini menunjukkan bahwa Manajemen rantai pasok beras di Kecamatan Kotamobagu Selatan dimulai dari petani berupa gabah kemudian didistribusikan oleh petani kepada penggilingan padi. Aktivitas pengeringan, penggilingan dan pengemasan dilakukan oleh penggilingan padi, kemudian dijual ke pedagang besar dan pedagang pengecer maupun langsung ke konsumen akhir dalam bentuk beras. Proses aktivitas dalam penerapan manajemen rantai pasok terbagi atas 3 aliran utama yang dikelola dengan baik, yaitu aliran barang/produk, aliran keuangan dan aliran informasi sehingga produksi beras di setiap anggota rantai pasok selalu tersedia.
\end{abstract}

Kata kunci: manajemen, rantai pasok, beras, Kecamatan Kotamobagu Selatan, Kota Kotamobagu

PENDAHULUAN

\section{Latar Belakang}

Di Indonesia, diketahui bahwa sektor pertanian memiliki peranan penting dalam perekonomian nasional. Hal ini dapat dilihat dari kemampuan sektor pertanian berkontribusi pada Produk Domestik Bruto (PDB), dalam penyerapan tenaga kerja, sumber ketersediaan pangan dan penciptaan kesempatan kerja atau usaha dalam peningkatan pendapatan masyarakat serta 
sebagai sumber perolehan devisa (Nadhwatunnaja, 2008). Penyediaan pangan terutama beras, dalam jumlah yang cukup dan harga yang terjangkau tetap menjadi tujuan utama pembangunan pertanian nasional. Beras yang merupakan makanan pokok lebih dari $95 \%$ penduduk Indonesia, juga menyediakan lapangan kerja bagi 21 juta rumah tangga melalui usaha tani padi (Sihombing, 2015). Jumlah penduduk yang semakin meningkat, ketidakcukupan akan pasokan beras dapat menyebabkan instabilitas sosial, ekonomi dan politik negara. Oleh karena itu, program peningkatan produksi padi senantiasa menjadi prioritas utama dalam pembangunan pertanian (Iskandar, 2011). Selain aspek produksi yang menentukan ketersediaan, aspek distribusi dan harga yang terjangkau juga merupakan komponen penting dalam menciptakan aksesbilitas masyarakat terhadap pangan, terutama beras (Lokollo, 2012). Tujuan pemerintah yaitu tersedianya pasokan harga beras yang stabil, tersedia sepanjang waktu, terdistribusi secara merata dan harga yang terjangkau. Kondisi ini menunjukkan bahwa perlu menerapkan konsep manajemen rantai pasok dalam memenuhi permintaan konsumen akan pasokan beras secara efektif dan efisien, baik dari sisi biaya, waktu dan proses (Salsabila, 2014).

Manajemen rantai pasok adalah tinjauan secara menyeluruh dan pengelolaan yang terpadu, terintegrasi dan saling terkait mulai dari hulu (input produksi) sampai ke hilir. Konsep manajemen rantai pasok tidak terbatas pada upaya memadukan kumpulan rantai pasok, namun mencakup pada seri aliran barang/jasa, keuangan dan informasi yang dilakukan oleh setiap pelaku rantai bisnis (Hadiguna, 2007). Sulawesi Utara merupakan salah satu provinsi yang memiliki beberapa sentra produksi beras, salah satunya di Kecamatan Kotamobagu Selatan. Hal ini ditunjukkan oleh banyaknya penduduk yang bermata pencaharian sebagai petani padi sawah dan didukung dengan luasnya lahan pertanian. Berikut ini data luas lahan padi sawah di Kecamatan Kotamobagu Selatan Tahun 2015 dapat di lihat pada Tabel 1.

\section{Tabel 1. Luas Lahan Padi Sawah di Kecamatan Kotamobagu Selatan Tahun 2015}

\section{Kelurahan}

\begin{tabular}{cc} 
Motoboi Kecil & 58,56 \\
Mongondow & 5,87 \\
Pobundayan & 7,57 \\
Poyowa Besar I & 211,49 \\
Poyowa Besar II & 108,33 \\
Tabang & 198,85 \\
Bungko & 164,32 \\
Kopandakan I & 129,47 \\
Poyowa Kecil & 123,06 \\
\hline Total & $\mathbf{1 0 0 7 , 5 2}$
\end{tabular}

Sumber : Dinas Pertanian Kota Kotamobagu, 2015.

Tabel 1 menggambarkan bahwa beberapa kelurahan yang ada di Kecamatan Kotamobagu Selatan berperan sebagai daerah yang memiliki luas lahan yang besar dan merupakan sentra produksi beras. Produksi beras yang dihasilkan bertujuan untuk menjaga stabilitas persediaan, mempertahankan maupun meningkatkan produksinya secara maksimal. Sehingga setiap permintaan konsumen beras dapat terpenuhi dengan baik. Dengan sembilan kelurahan yang ada di Kecamatan Kotamobagu Selatan, berpotensi besar dalam menunjang pembangunan perekonomian daerah dan sampai saat ini menjadi penyumbang produksi beras di Kota Kotamobagu maupun luar daerah.

\section{Perumusan Masalah}

Bagaimana manajemen rantai pasok beras di Kecamatan Kotamobagu Selatan Kota Kotamobagu ?

\section{Tujuan dan Manfaat Penelitian}

Tujuan penelitian ini yaitu untuk mengidentifikasi dan mengkaji tentang manajemen rantai pasok beras di Kecamatan Kotamobagu Selatan Kota Kotamobagu. Manfaat dari penelitian ini yaitu untuk memberikan informasi tentang manajemen rantai pasok beras di Kecamatan Kotamobagu Selatan Kota Kotamobagu baik kepada pemerintah, masyarakat maupun kepada pihak yang membutuhkan. 


\section{METODOLOGI PENELITIAN}

\section{Lokasi dan Waktu Penelitian}

Penelitian ini dilakukan di Kecamatan Kotamobagu Selatan Kota Kotamobagu. Waktu penelitian yakni dimulai pada bulan Oktober Tahun 2016 sampai bulan Februari Tahun 2017.

\section{Metode Pengumpulan Data}

Data yang digunakan pada penelitian adalah data primer dan sekunder. Data primer yaitu dengan wawancara langsung dengan menggunakan daftar pertanyaan (kuisener) kepada anggota rantai pasok beras di Kecamatan Kotamobagu Selatan yaitu, petani, penggilingan padi, pedagang besar, pedagang pengecer dan konsumen akhir. Data yang diambil adalah identitas responden, keadaan usahatani padi secara umum, kondisi rantai pasok disetiap rantai, hubungan antar rantai secara keseluruhan dan informasi disetiap anggota rantai pasok. Sedangkan data sekunder adalah data yang diperoleh dan dikumpulkan berdasarkan hasil studi pustaka dan dari dinas/instansi terkait guna kepentingan penelitian. Data yang diambil yaitu di Dinas Pertanian Kota Kotamobagu tentang luas lahan padi sawah di Kecamatan Kotamobagu Selatan Tahun 2015.

\section{Metode Pengambilan Sampel}

Metode pengambilan sampel dilakukan dengan cara Snowball Sampling, dimana sampel diperoleh berdasarkan informasi dari responden pertama yaitu petani di Kecamatan Kotamobagu Selatan selanjutnya ditelusuri ke penggilinggan padi, pedagang besar, pedagang pengecer hingga ke tingkat konsumen akhir.

\section{Konsep Pengukuran Variabel}

Variabel-variabel yang diukur dalam penelitian ini adalah sebagai berikut:

\section{Pengadaan}

a. Pemilihan pemasok saprodi (benih/bibit, pupuk dan pestisida) oleh tingkat petani

b. Pemilihan pemasok gabah oleh tingkat penggilingan

c. Pemilihan pemasok beras oleh tingkat pedagang besar, pedagang pengecer dan konsumen akhir d. Kegiatan pembelian saprodi oleh tingkat petani

e. Kegiatan pembelian gabah oleh tingkat penggilingan

f. Kegiatan pembelian beras oleh tingkat pedagang besar, pedagang pengecer dan konsumen akhir

g. Mengevaluasi kinerja/kegiatan pemasok saprodi kepada petani, petani dalam bentuk gabah kepada penggilingan dan penggilingan dalam bentuk beras kepada pedagang besar, pedagang pengecer maupun langsung ke konsumen akhir

h. Membina dan memelihara hubungan kerjasama antar pemasok saprodi, pemasok gabah dan pemasok beras.

\section{Perencanaan dan Pengendalian}

a. Perencanaan kebutuhan saprodi sesuai dengan permintaan petani $(\mathrm{kg})$

b. Pengendalian persediaan pasokan gabah oleh petani akan permintaan dari tingkat pengggilingan $(\mathrm{kg})$

c. Perencanaan dan pesediaan pasokan gabah dikaitkan dengan informasi tentang jumlah permintaan gabah dari tingkat penggilingan $(\mathrm{kg})$

d. Perencanaan kapasitas atau jumlah yang akan di produksi di penggilingan yaitu gabah menjadi beras $(\mathrm{kg})$

e. Pengendalian kualitas dan mutu beras

f. Perencanaan mengenai jumlah beras yang akan didistribusikan kepada pedagang besar, pedagang pengecer maupun langsung ke konsumen akhir.

\section{Operasi/Produksi}

a. Penjadwalan produksi oleh tingkat penggilingan dikaitkan dengan jumlah beras $(\mathrm{kg})$

b. Kegiatan pengolahan produksi gabah menjadi beras terkait permintaan dan informasi disesuaikan dengan jumlah beras $(\mathrm{kg})$

c. Pemakaian tenaga kerja (Rp/HOK)

d. Biaya pengolahan gabah menjadi beras (Rp)

4. Pengiriman/Distribusi

a. Perencanaan distribusi/pengiriman beras kepada pedagang besar, pedagang pengecer 
maupun langsung ke konsumen akhir sesuai dengan jumlah permintaan $(\mathrm{kg})$

b. Penjadwalan pengiriman beras dari penggilingan kepada pedagang besar, pedagang pengecer maupun langsung ke konsumen akhir (waktu dan ketepatan pengiriman)

c. Pengiriman pasokan beras sesuai jumlah permintaan yang di butuhkan $(\mathrm{kg})$

d. Biaya transportasi dari penggilingan kepada pedagang besar, pedagang pengecer maupun langsung ke konsumen akhir (Rp)

e. Memonitor pergerakan pasokan beras di setiap pusat distribusi dari penggilingan kepada pedagang besar, pedagang pengecer maupun langsung ke konsumen akhir (waktu dan ketepatan pengiriman)

\section{Analisis Data}

Analisis data yang digunakan dengan metode deskriptif meliputi petani, penggilingan padi, pedagang besar, pedagang pengecer dan konsumen akhir untuk mengetahui struktur manajemen rantai pasok dan mekanisme rantai pasok yang terkait aliran produk/barang, aliran keuangan dan aliran informasi pada manajemen rantai pasok beras di Kecamatan Kotamobagu Selatan Kota Kotamobagu.

\section{HASIL DAN PEMBAHASAN}

\section{Deskripsi Wilayah Penelitian}

\section{Keadaan Geografis Penelitian}

Kota Kotamobagu merupakan salah satu wilayah yang terletak di provinsi Sulawesi Utara, terletak antara $0^{\circ} 30^{\prime}-1^{\circ} 0^{\prime}$ Lintang Utara dan $123^{\circ}$ Bujur Timur. Kota Kotamobagu secara administratif terbagi ke dalam empat kecamatan, salah satunya yaitu Kecamatan Kotamobagu Selatan. Kecamatan Kotamobagu Selatan adalah salah satu kecamatan yang ada di Kota Kotamobagu. Kecamatan Kotamobagu Selatan terdiri dari sembilan Kelurahan/Desa dengan luas wilayah 8660,64 ha. Batas-batas wilayah Kecamatan Kotamobagu Selatan adalah sebagai berikut :

1. Sebelah Utara berbatasan dengan Kelurahan Sinindian (Kotamobagu Timur)

2. Sebelah Selatan berbatasan dengan Kabupaten Bolaang Mongondow Induk
3. Sebelah Timur berbatasan dengan Kelurahan Kotabangon (Kotamobagu Timur)

4. Sebelah Barat berbatasan dengan Kelurahan Mongkonai Kecamatan Kotamobagu Barat.

\section{Jumlah Penduduk}

Penduduk di Kecamatan Kotamobagu Selatan berjumlah 19.304 jiwa, dengan jumlah penduduk laki-laki sebanyak 10.078 jiwa dan perempuan 9226 jiwa serta jumlah KK (Kepala Keluarga) sebanyak $4.539 \mathrm{KK}$.

\section{Mata Pencaharian}

Tingkat perekonomian di Kecamatan Kotamobagu Selatan umumnya ditentukan oleh sektor pertanian. Sebagai mata pencaharian adalah bertani seperti tanaman pangan yaitu padi sawah.

\section{Karakteristik Responden}

\section{Umur Petani}

Umur petani akan sangat mempengaruhi produktivitas dari petani dalam bekerja atau perannya dalam pengambilan keputusan di berbagai alternatif pekerjaan yang dilakukannya dan mempengaruhi kemampuan seseorang untuk bekerja secara fisik maupun cara berpikirnya. Cara berpikir dan kemampuan fisik petani sangat dipengaruhi oleh tingkat umur. Semakin tinggi umur makin berkurang kemampuan dalam bekerja, sedangkan petani yang berumur mudah pada umumnya mempunyai kemampuan fisik yang lebih baik. Menurut hasil penelitian umur petani responden dapat dilihat pada Tabel 2.

\section{Tabel 2. Jumlah dan Persentase Menurut} Umur Petani Responden

\begin{tabular}{cccc}
\hline No & $\begin{array}{c}\text { Umur } \\
\text { (Tahun) }\end{array}$ & $\begin{array}{c}\text { Jumlah } \\
\text { Responden } \\
\text { (Orang) }\end{array}$ & $\begin{array}{c}\text { Persentase } \\
(\%)\end{array}$ \\
\hline 1 & $31-35$ & 7 & 15.56 \\
2 & $36-40$ & 13 & 28.89 \\
3 & $41-45$ & 11 & 24.44 \\
4 & $46-50$ & 9 & 20.00 \\
5 & $51-55$ & 5 & 11.11 \\
\hline Total & & $\mathbf{4 5}$ & $\mathbf{1 0 0}$ \\
\hline
\end{tabular}

Sumber : Data Primer yang Diolah, 2017

Tabel 2 dapat dilihat bahwa kelompok umur $<40$ sebanyak 20 orang petani atau 44,43 $\%$ dari total petani responden dan untuk 
kelompok umur $>40$ sebanyak 25 atau 55,55\% dari total petani responden.

\section{Tingkat Pendidikan}

Pendidikan mempunyai peran penting dalam proses memperoleh dan meningkatkan kualitas, kemampuan dan individu. Pendidikan penting untuk dilakukan karena sangat berguna bagi pembentukan dan pengembangan pribadi serta intelektual petani. Pendidikan seseorang sangat mempengaruhi cara berpikir dan bertindak sehingga dalam melaksanakan suatu kegiatan dapat mempertimbangkan berbagai hal yang dapat menguntungkan dan merugikan dan dapat menentukan alternatif kegiatan yang dilakukan. Dari hasil penelitian diperoleh bahwa tingkat pendidikan petani yaitu mulai dari tingkat sekolah dasar (SD) sampai perguruan tinggi seperti pada Tabel 3 .

\section{Tabel 3. Tingkat Pendidikan dan Persentase Petani Responden}

\begin{tabular}{cccc}
\hline No & $\begin{array}{c}\text { Tingkat } \\
\text { Pendidikan }\end{array}$ & $\begin{array}{c}\text { Jumlah } \\
\text { Responden } \\
\text { (Orang) }\end{array}$ & $\begin{array}{c}\text { Persentase } \\
\mathbf{( \% )}\end{array}$ \\
\hline 1 & SD & 15 & 33.33 \\
2 & SMP & 22 & 48.89 \\
3 & SMA & 2 & 4.44 \\
4 & S1 & 6 & 13.33 \\
\hline & Total & $\mathbf{4 5}$ & $\mathbf{1 0 0}$
\end{tabular}

Sumber :Data Primer yang Diolah, 2017

Berdasarkan hasil penelitian, tingkat pendidikan yang dimiliki petani tertinggi berada pada tingkat pendidikan SMP yaitu 48,88 \% dengan jumlah petani responden 22 orang, kemudian pada tingkat sekolah dasar (SD) yaitu $33,33 \%$ dengan jumlah petani responden 15 orang, sedangkan tingkat SMA yaitu 4,44\% dengan jumlah petani responden dua orang dan tingkat S1 yaitu 13,33\% dengan jumlah petani responden enam orang.

\section{Jumlah Tanggungan}

Tanggungan keluarga dalam hal ini, merupakan jumlah anggota keluarga yang masih menjadi tanggungan dalam satu keluarga. Banyak anggota keluarga mempengaruhi penghasilan dalam suatu usaha tani. Jumlah anggota keluarga petani responden di Kecamatan Kotamobagu Selatan berjumlah orang. Jumlah tanggungan keluarga responden dapat dilihat pada Tabel 4.

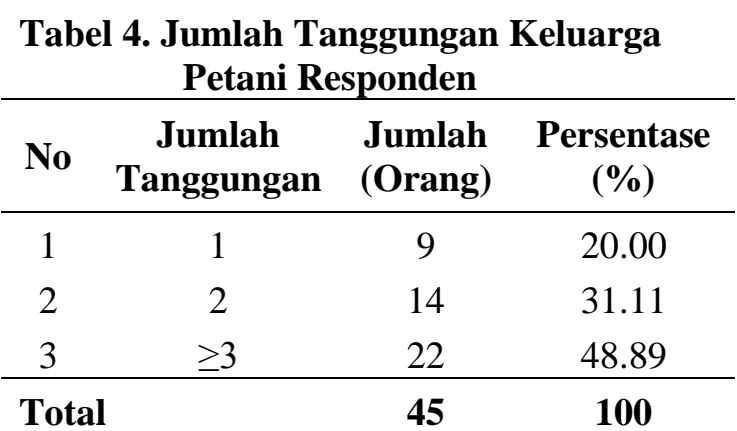

Sumber : Data Primer yang Diolah, 2017

Tabel 4 menunjukkan bahwa tanggunggan keluarga petani responden $<14$ orang sebanyak 23 orang atau 51,11\% dan jumlah tanggungan total $>14$ sebanyak 22 orang atau $48,88 \%$. Pada umumnya anggota keluarga yang terhitung dalam jumlah tanggungan ini membantu dalam hal penyediaan tenaga kerja. Dengan demikian ketersediaan tenaga kerja dalam keluarga akan mempengaruhi penyerapan tenaga kerja dari luar keluarga. Tetapi dilain pihak makin banyak anggota keluarga maka makin besar pula biaya yang diperlukan untuk memenuhi keperluan keluarga.

\section{Luas Lahan Usahatani Padi Sawah}

Lahan yang ada di Kecamatan Kotamobagu Selatan banyak dimanfaatkan untuk tanaman pangan di antaranya padi sawah. Berikut ini luas lahan yang diusahakan petani responden dapat dilihat pada Tabel 5.

Tabel 5. Luas Lahan yang diusahakan

\begin{tabular}{ccc}
$\begin{array}{c}\text { Luas Lahan } \\
\text { (Ha) }\end{array}$ & $\begin{array}{c}\text { Jumlah Petani } \\
\text { (Orang) }\end{array}$ & $\begin{array}{c}\text { Persentase } \\
(\boldsymbol{\%})\end{array}$ \\
\hline$<1,0$ & 2 & 4.44 \\
$1,0-2,0$ & 31 & 68.89 \\
$>2,0$ & 12 & 26.67 \\
\hline Total & $\mathbf{4 5}$ & $\mathbf{1 0 0}$ \\
\hline
\end{tabular}

Sumber : Data Primer yang Diolah, 2017

Tabel 5 dapat dilihat bahwa petani responden banyak mengusahakan lahan untuk 
usaha tani padi sawah berada pada luas $1,0-$ 2,0 ha dengan jumlah responden petani 31 orang atau $68,88 \%$.

\section{Penggunaan Sarana Produksi Padi Sawah :}

\section{1) Pengolahan Lahan}

Dalam pengolahan lahan pada usahatani padi sawah di Kecamatan Kotamobagu Selatan menggunakan traktor, ternak dan cangkul seperti yang terlihat pada Tabel 6 .

Tabel 6. Teknik Pengolahan Lahan Petani Padi Sawah

\begin{tabular}{|c|c|c|c|}
\hline \multicolumn{4}{|c|}{ Sawan } \\
\hline No & $\begin{array}{c}\text { Teknik } \\
\text { Pengolahan } \\
\text { Lahan }\end{array}$ & $\begin{array}{c}\text { Jumlah } \\
\text { Petani } \\
\text { (Orang) }\end{array}$ & $\begin{array}{c}\text { Persentase } \\
(\%)\end{array}$ \\
\hline & Menggunakan & & \\
\hline 1 & Traktor & 43 & 95.56 \\
\hline & Menggunakan & & \\
\hline 2 & Ternak & 1 & 2.22 \\
\hline & Menggunakan & & \\
\hline 3 & Cangkul & 1 & 2.22 \\
\hline & Total & 45 & 100 \\
\hline
\end{tabular}

Sumber : Data Primer yang Diolah, 2017

Tabel 6 dapat dilihat bahwa petani responden yang menggunakan traktor dalam pengolahan lahan ada 43 petani responden atau $95,55 \%$. Sedangkan yang paling sedikit yang ada satu petani responden atau 2,22\% orang yang menggunakan ternak (milik sendiri) dan ada satu orang petani responden atau 2,22\% yang menggunakan cangkul untuk pengolahan lahan. Petani di Kecamatan Kotamobagu Selatan melakukan pengolahan lahan menggunakan traktor dengan sistem borong dengan biaya sewa traktor Rp.200.000 250.000 per hari dengan kapasitas kerja untuk bajak 1,5 - 2,0 Ha/hari. Biaya sewa traktor bervariasi disesuaikan dengan luas lahan yang ingin di garap. Pengolahan lahan dengan sistem ini memiliki kelebihan diantaranya lebih cepat dalam proses pengerjaan, serta dapat menghemat waktu penanaman, sedangkan pengolahan lahan menggunakan ternak (milik sendiri) dan menggunakan cangkul biasanya petani yang ada di Kecamatan Kotamobagu Selatan menggunakannya untuk jenis lahan yang sempit dan sangat jarang petani menggunakan tenaga ternak dan cangkul untuk pengolahan lahan karena memakan banyak waktu dan banyak tenaga yang akan dibutuhkan.

\section{2). Penggunaan Benih/bibit}

Benih/bibit padi sawah sebagian diperoleh dari bantuan pemerintah Kota Kotamobagu melalui Dinas PPL (Pengawas Penyuluh Lapangan) Kecamatan Kotamobagu Selatan. Bantuan yang diberikan sesuai dengan jumlah yang disediakan oleh pemerintah. Selain itu juga melalui pertukaran dengan sesama petani, sebelum melakukan pertukaran, petani melakukan perencanaan kebutuhan (benih/bibit) sesuai jumlah yang dibutuhkan dan sebagian petani membeli langsung dikios yang berada di Kecamatan Kotamobagu Selatan dengan harga Rp. 100.000-150.000/karung atau sesuai dengan jenisnya. Ketersediaan benih/bibit merupakan kerjasama yang dilakukan sehingga benih/bibit yang dibutuhkan petani selalu tersedia. Berikut ini distirbusi petani menurut varietas benih yang digunakan dapat dilihat pada Tabel 7.

Tabel 7. Distribusi Petani Menurut Varietas Benih yang Digunakan

\begin{tabular}{ccc}
\hline \multirow{2}{*}{$\begin{array}{c}\text { Varietas Padi } \\
\text { Sawah }\end{array}$} & \multicolumn{2}{c}{ Jumlah Petani } \\
\cline { 2 - 3 } & Orang & $\begin{array}{c}\text { Persentase } \\
(\mathbf{\%})\end{array}$ \\
\hline Lokal & 41 & 91.11 \\
Hibrida & 1 & 2.22 \\
Unggul Nasional & 3 & 6.67 \\
\hline Total & $\mathbf{4 5}$ & $\mathbf{1 0 0}$ \\
\hline
\end{tabular}

Sumber : Data Primer yang Diolah, 2017

Tabel 7 menunjukkan bahwa petani responden banyak menggunakan benih padi lokal (Serayu, Superwin, Sultan) yaitu 41 petani responden atau $91,11 \%$ dan untuk benih unggul nasional (ceheran) tiga petani responden atau $6,66 \%$, sedangkan benih hibrida (Intani) satu petani responden atau $2,22 \%$.

\section{3). Penggunaan Herbisida}

Jenis herbisida yang digunakan adalah DMA 6 untuk mengendalikan gulma daun lebar dan basmilang untuk daun sempit. Jumlah petani responden yang menggunakan herbisida sebanyak 16 petani atau $35,55 \%$, dengan harga 
Rp.40.000/botol. Dari hasil penelitian rata-rata yang digunakan yaitu 3 - 5 botol per hektar sesuai dengan areal luas lahan yang dibutuhkan.

\section{4). Penggunaan Pestisida}

Hasil penelitian menunjukkan bahwa pada umumnya petani memperoleh pestisida yang dibeli dari kios yang berada di Kecamatan Kotamobagu Selatan . Jenis dan harga pestisida bervariasi yaitu Score Rp.75.000/botol, Alika Rp. 75.000/botol, Pastak Rp.45.000/botol, Regen Rp. 75.000/botol dan Rambo Rp.70.000/botol. Sebagian juga diperoleh bantuan dari pemerintah Kota Kotamobagu melalui Dinas PPL (Pengawas Penyuluh Lapangan) Kecamatan Kotamobagu Selatan. Bantuan pestisida yang diberikan sesuai dengan jumlah yang disediakan oleh pemerintah. Berikut ini penggunaan pestisida usahatani padi sawah dapat dilihat pada Tabel 8 .

Tabel 8. Penggunaan Pestisida Usahatani Padi Sawah

\begin{tabular}{cccc} 
No & $\begin{array}{c}\text { Jenis } \\
\text { Pestisida }\end{array}$ & $\begin{array}{c}\text { Jumlah Petani } \\
\text { (Orang) }\end{array}$ & $\begin{array}{c}\text { Persentase } \\
(\%)\end{array}$ \\
\hline 1 & Alika & 45 & 100 \\
2 & Regen & 45 & 100 \\
3 & Pastak & 5 & 11.11 \\
4 & Score & 6 & 13.33 \\
5 & Rambo & 2 & 4.44 \\
\hline
\end{tabular}

Sumber: Data Primer yang Diolah, 2017

Tabel 8, pestisida yang digunakan pada umumnya adalah Alika (100\%), Regen (100\%), Pastak $(11,11 \%)$ atau lima orang petani responden, Score $(13,33 \%)$ atau enam orang petani responden dan Rambo $(4,44 \%)$ atau dua orang petani responden. Sebagian besar petani padi sawah di Kelurahan Kotamobagu Selatan menggunakan pestisida Alika dan Regen. Hasil penelitian mendapati bahwa rata-rata pestisida yang digunakan yaitu berjumlah 4 - 6 botol per hektar dan penggunaan pestisida di sesuaikan dengan kondisi yang terjadi di areal pertanaman.

\section{5). Penggunaan Pupuk}

Pupuk yang digunakan oleh petani pada umumnya adalah Urea, TSP, KCL dan Phonska. Secara rinci jenis penggunaan pupuk oleh petani responden dapat dilihat pada Tabel 9.
Tabel 9. Penggunaan Pupuk Usahatani Padi Sawah

\begin{tabular}{cccc}
\hline No & $\begin{array}{c}\text { Jenis } \\
\text { Pupuk }\end{array}$ & $\begin{array}{c}\text { Jumlah Petani } \\
\text { (Orang) }\end{array}$ & $\begin{array}{c}\text { Persentase } \\
(\boldsymbol{\%})\end{array}$ \\
\hline 1 & Urea & 45 & 100 \\
2 & TSP & 39 & 86.66 \\
3 & KCL & 23 & 51.11 \\
4 & Phonska & 23 & 51.11 \\
\hline
\end{tabular}

Sumber : Data Primer yang Diolah, 2017

Pada umumnya petani memperoleh pupuk yang dibeli dari kios yang berada di Kecamatan Kotamobagu Selatan dengan harga pupuk yang berlaku yaitu Urea Rp.110.000/karung, TSP/SP36 Rp. 100.000/karung, KCL Rp. 100.000/karung dan Ponska Rp. 100.000/karung. Sebagian diperoleh bantuan dari pemerintah Kota Kotamobagu melalui Dinas PPL (Pengawas Penyuluh Lapangan) Kecamatan Kotamobagu Selatan. Bantuan pupuk yang diberikan sesuai dengan jumlah yang disediakan oleh pemerintah.

\section{6). Penggunaan Tenaga Kerja}

Tenaga kerja merupakan masyarakat yang berasal dari dalam keluarga maupun luar keluarga. Tenaga kerja dari dalam keluarga digunakan khusus pada kegiatan persemaian dan pemeliharaan, sedangkan tenaga kerja diluar keluarga digunakan pada kegiatan pengolahan lahan, penen dan pasca panen dengan menggunakan upah kerja per hari. Tenaga kerja tersebut diberi upah oleh petani yang berbeda-beda, pria Rp. 150.000/hari sedangkan wanita Rp. 120.000/hari.

\section{Struktur Manajemen Rantai Pasok Beras Di Kecamatan Kotamobagu Selatan Kota Kotamobagu}

Struktur manajemen rantai pasok beras di Kecamatan Kotamobagu Selatan dapat dianalisis melalui anggota-anggota yang membentuk rantai pasok dan peran masingmasing anggota rantai pasok. Untuk mendapatkan pemahaman tentang sistem manajemen rantai pasok gabah/beras di daerah penelitian, dilakukan kajian tentang kegiatan dari berbagai pelaku dalam rantai pasok beras. 
Data dan informasi kegiatan dalam rantai pasok oleh petani, penggilingan padi, pedagang besar, pedagang pengecer dan konsumen akhir terkait pengadaan, perencanaan dan pengendalian, produksi dan pengiriman/distribusi, yaitu sebagai berikut :

\section{Tingkat Petani}

Petani merupakan anggota rantai yang mengawali rantai pasok beras. Petani ini berperan penting pada rantai pasok beras karena kualitas dan kuantitas pasokan beras sangat ditentukan olehnya. Terdapat 93 petani padi yang ada di Kecamatan Kotamobagu Selatan yang bermitra dengan pihak penggilingan dengan masing-masing sembilan petani per kelurahan. Gabah yang telah dipanen, tidak semua dijual kepada penggilingan karena petani juga menyimpan sebagian hasil panen mereka untuk kebutuhan konsumsi keluarga sehari-hari. Petani sudah melakukan perencanaan untuk jumlah/kapasitas akan produksi gabah yaitu panen untuk beberapa bulan berikutnya sehingga setiap permintaan oleh penggilingan selalu berlanjut dan selalu tersedia. Selain itu petani sudah melakukan persediaan pasokan gabah melalui informasi yang disampaikan tentang jumlah dan permintaan gabah dari penggilingan.

Padi yang telah dipanen akan disortir kembali oleh petani untuk pengemasan per karung gabah yang disediakan oleh petani sendiri yaitu $25 \mathrm{~kg} / \mathrm{karung}$ dan akan dibawa ke penggilinggan di Kecamatan Kotamobagu Selatan yakni, Penggilinggan Toko Berkat, Penggilinggan Bapak Yunus, Penggilinggan RAPE, Penggilinggan Ibu Nansi Kereh, Penggilinggan Tani Sejahtera, Penggilinggan Bapak Adrian Wawuruntu, Penggilinggan Mapalus, Penggilinggan Ibu Suli Rompas dan Penggilingugan PG. Pengangkutan gabah dilakukan dengan mobil pick up milik penggilinggan padi dan dimonitor langsung oleh petani dan pihak penggilingan agar pergerakan pasokan gabah yang akan dikirim kepada penggilingan sesuai dengan waktu dan jumlah yang di butuhkan. Jumlah produksi padi sawah sangat bervariasi tergantung dari tingkat perawatannya. Bila tanaman tersebut dirawat dengan baik, dalam artian dibersihkan secara teratur, pemupukan yang tepat dan pengendalian hama yang terpadu maka produksi tanaman tersebut akan maksimal. Berikut ini rata-rata produksi padi sawah di Kecamatan Kotamobagu Selatan dapat dilihat pada Tabel 10.

Tabel 10. Produksi Padi Sawah Rata-Rata per Responden Menurut Lokasi Sampel

\begin{tabular}{|c|c|c|c|c|}
\hline \multirow[b]{2}{*}{ Kelurahan } & \multirow[b]{2}{*}{$\mathbf{N}$} & \multicolumn{3}{|c|}{ Produksi (Kg) } \\
\hline & & GKG & $\begin{array}{c}\text { Pasok } \\
\text { Ke } \\
\text { Penggili } \\
\text { ngan }\end{array}$ & Beras \\
\hline \multicolumn{5}{|l|}{ Motoboi } \\
\hline Kecil & 5 & 10.400 & 6.900 & 5.500 \\
\hline Mongondow & 5 & 8.800 & 8.800 & 7.200 \\
\hline $\begin{array}{c}\text { Pobundayan } \\
\text { Poyowa }\end{array}$ & 5 & 11.500 & 11.500 & 9.300 \\
\hline Besar I & 5 & 12.800 & 12.800 & 9.700 \\
\hline \multicolumn{5}{|l|}{ Poyowa } \\
\hline Besar II & 5 & 11.600 & 11.600 & 9.200 \\
\hline Tabang & 5 & 11.900 & 11.900 & 10.100 \\
\hline Bungko & 5 & 17.200 & 17.200 & 11.200 \\
\hline \multicolumn{5}{|l|}{ Kopandakan } \\
\hline I & 5 & 14.850 & 14.850 & 8.500 \\
\hline \multicolumn{5}{|l|}{ Poyowa } \\
\hline Kecil & 5 & 20.300 & 9200 & 5.600 \\
\hline Jumlah & 45 & 119.350 & 104.750 & 76.300 \\
\hline Rata-Rata & 5 & $2.652,22$ & 2.327,77 & $1.695,55$ \\
\hline
\end{tabular}

Sumber : Data Primer yang Diolah, 2017

Tabel 10 menunjukkan bahwa dalam satu kali periode panen dengan jumlah produksi padi sawah di Kecamatan Kotamobagu Selatan sebesar $119.350 \mathrm{~kg}$ GKG per hektar dengan rata-rata $2.652,22 \mathrm{~kg}$ GKG per hektar. Kemudian gabah tersebut dipasok ke penggilingan sebesar $104.750 \mathrm{~kg}$ dengan ratarata $2.327,77$. Jika dihitung dalam bentuk beras maka jumlah produksi beras sebesar $76.300 \mathrm{~kg}$ dengan rata-rata $1.695,55 \mathrm{~kg}$.

\section{Tingkat Penggilinggan Padi}

Menurut hasil penelitian, terdapat $2-3$ tempat penggilingan pada setiap kelurahan dan terdapat 93 petani di Kecamatan Kotamobagu Selatan, dengan masing-masing sembilan petani yang bermitra dengan penggilingan pada setiap kelurahan. 
Awalnya petani mengadakan kerjasama dengan pihak penggilingan berupa bantuan pinjaman modal untuk biaya pengolahan lahan, biaya penggunaan saprodi dan biaya tenaga kerja. Setelah panen, petani akan mengembalikan bantuan pinjaman modal tersebut kepada pihak penggilingan berupa gabah yang dihasilkan dan harga jual disesuaikan dengan harga pasar. Kemudian dilakukan kegiatan pengiriman gabah sesuai dengan jumlah yang telah disepakati. Berikut ini data rata-rata pemasok gabah, jumlah dan rata-rata gabah yang dipasok dan frekuensi, dapat dilihat pada Tabel 11.

Tabel 11. Rata-rata Pemasok Gabah, Jumlah dan Rata-rata Gabah yang dipasok dan Frekuensi

\begin{tabular}{cc}
\hline $\begin{array}{c}\text { Rata-Rata Pemasok } \\
\text { Gabah }\end{array}$ & $\begin{array}{c}\text { 9 Petani per } \\
\text { Kelurahan }\end{array}$ \\
\hline & $104.750 / \mathrm{kg}$ (jumlah) \\
dan \\
Jumlah dan rata-rata & $2.327,77 / \mathrm{kg}$ (rata- \\
gabah yang dipasok & rata) \\
\hline Frekuensi & $3-4$ kali $/$ tahun \\
\hline
\end{tabular}

Sumber : Data Primer yang Diolah, 2017

Setelah gabah dipasok, selanjutnya kegiatan pengolahan gabah menjadi beras mulai dari kegiatan pengeringan, penggilingan dan pengemasan dilakukan oleh penggilingan padi yang ada di Kecamatan Kotamobagu Selatan. Dengan kata lain, kegiatan penambahan nilai kebanyakan terkonsentrasi pada penggilingan padi. Penggunaan tenaga kerja berasal dari daerah di sekitar Kecamatan Kotamobagu Selatan untuk melakukan kegiatan penjemuran gabah, perontokkan dan penggilinggan, pengangkutan, sortasi, pengemasan, pelabelan dengan upah harian yang berbeda-beda, pria Rp. 150.000/hari sedangkan untuk wanita Rp. 120.000/hari. Kegiatan distribusi dari penggilingan ke pedagang beras bergantung pada kesepakatan yang telah direncanakan. Ada kalanya pengiriman dilakukan oleh penggilingan sampai ke pedagang beras melalui proses transportasi kendaraan yang dimiliki oleh penggilingan sendiri dengan menggunakan biaya sewa kendaraan sebesar Rp. 200.000 - 300.000/hari. Proses pengiriman/distribusi disesuiakan dengan lokasi tujuan. Ada juga pedagang besar/pedagang pengecer maupun konsumen akhir datang langsung ke penggilingan untuk melakukan mitra kerja yaitu dari Pasar Serasi Kotamobagu, Toko Berkat Kotamobagu, Pasar Bersehati Manado, Pasar 23 Maret Manado, Pasar Gorontalo dan Pasar Boltim.

Penggilinggan sudah ada perencanaan untuk jumlah pasokan beras yang telah diproduksi dan akan didistribusikan kepada pedagang beras. Beras yang diproduksi tersebut dijual kepada pedagang besar, pedagang pengecer maupun langsung ke konsumen akhir. Pedagang besar sebesar 20\%, pedagang pengecer sebesar $70 \%$ dan konsumen akhir sebesar $10 \%$. Besarnya beras yang dipasok pada masing-masing lembaga pemasaran disesuaikan dengan permintaan dari masingmasing lembaga tersebut. Penggilinggan tidak hanya menjual beras ke pedagang besar/pedagang pengecer, tetapi penggilinggan juga melayani konsumen yang datang membeli langsung yaitu konsumen dari Kotamobagu, Manado, Amurang, Gorontalo dan Boltim. Terdapat tiga jenis beras yang diproduksi oleh penggilinggan yaitu Serayu, Superwin dan Sultan. Rata-rata harga beras sebesar Rp.10.000/kg atau Rp.560.000/karung.

\section{Tingkat Pedagang Besar}

Pedagang besar yang ada di Kecamatan Kotamobagu Selatan berjumlah 3 orang yakni Bapak Muhardi (Pobundayan), Bapak As (Motoboi Kecil) dan Bapak Steven (Poyowa Besar I). Pedagang besar juga melakukan mitra kerja dengan pengecer dan hanya bekerjasama jika anggota rantai pasok tersebut mudah dipercaya (modal kepercayaan) untuk pasokan beras yang akan diproduksi dan untuk harga pembelian berbeda sehingga dari awal hanya sedikit pengecer yang melakukan kerjasama dengan pihak pedagang besar. Penjadwalan distribusi/pengiriman pasokan beras ke pengecer sudah ditentukan oleh pedagang besar sendiri yang lebih mengutamakan ketepatan waktu pengiriman sesuai tempat tujuan dan jumlah sesuai permintaan kebutuhan. Harga 
jual beras sebesar Rp. 10.000/kg Rp.11.000/kg sesuai dengan jenis beras.

\section{Tingkat Pedagang Pengecer}

Kegiatan pertama yang dilakukan pengecer yaitu melakukan pemilihan pemasok beras melalui pedagang besar maupun langsung ke penggilingan. Selanjutnya melakukan kegiatan pembelian beras sesuai dengan jumlah kebutuhan oleh pedagang pengecer. Untuk mengatasi ketersediaan pasokan beras untuk selalu tersedia, pedagang pengecer memonitor pergerakan pasokan beras terkait jumlah yang telah disepakati bersama. Tujuan kerjasama yang dilakukan yaitu agar setiap permintaan oleh konsumen akan selalu terpenuhi. Harga jual beras ke konsumen akhir Rp. $12.000 / \mathrm{kg}$. Terdapat beberapa konsumen akhir beras yaitu dari Kotamobagu, Boltim, Amurang, Manado dan Gorontalo.

\section{Tingkat Konsumen Akhir}

Konsumen akhir merupakan anggota rantai pasok beras yang terakhir dan menjadi tujuan akhir rantai pasok. Kualitas beras menjadi atribut utama dalam pembelian beras oleh konsumen dan konsumen akhir berperan dalam menentukan kualitas produk yang diinginkan dalam rantai pasok beras. Kualitas yang diinginkan akan disampaikan konsumen akhir kepada pengecer yang kemudian disampaikan hingga kepada petani yang ada di Kecamatan Kotamobagu Selatan. Tingkat konsumen akhir yaitu dari Kotamobagu, Gorontalo, Boltim, Amurang dan Manado.

\section{Mekanisme Aliran Produk, Aliran Keuangan dan Aliran informasi pada Manajemen Rantai Pasok Di Kecamatan Kotamobagu Selatan}

Proses aktivitas dalam penerapan manajemen rantai pasok beras di Kecamatan Kotamobagu Selatan memiliki tiga aliran/mekanisme yang harus dikelola dengan baik, yaitu aliran produk/barang, aliran keuangan dan alirang informasi.

\section{Aliran Produk/Barang}

Aliran produk/barang dalam rantai pasok beras di Kecamatan Kotamobagu Selatan mengalir dari hulu ke hilir dan dapat dibedakan menjadi dua macam aliran yaitu gabah dari petani ke penggilingan dan beras dari penggilingan ke pedagang besar, pedagang pengecer dan konsumen akhir.

\section{a. Aliran produk berupa gabah dari petani ke penggilingan}

Petani gabah di Kecamatan Kotamobagu Selatan mendistribusikan hasil panennya berupa gabah kepada beberapa lembaga pemasaran. Lembaga pemasaran yang di maksud adalah penggilinggan padi. Petani panen gabah dari lahannya selanjutnya dikemas dengan karung yang disediakan oleh petani sendiri berisi $25 \mathrm{~kg} / \mathrm{karung}$. Proses pengangkutan gabah dari petani biasanya dilakukan oleh penggilingan menggunakan mobil pick up dan truk. Biaya yang dikeluarkan oleh penggilingan adalah upah buruh sebesar Rp. 150.000/orang. Penggilinggan yang ada di Kecamatan Kotamobagu Selatan yakni, Penggilinggan Toko Berkat, Penggilinggan Bapak Yunus, Penggilinggan RAPE, Penggilinggan Ibu Nansi Kereh, Penggilinggan Tani Sejahtera, Penggilinggan Bapak Adrian Wawuruntu, Penggilinggan Mapalus, Penggilinggan Ibu Suli Rompas dan Penggilinggan PG.

\section{b. Aliran produk berupa beras dari} penggilingan ke pedagang besar, pengecer dan konsumen akhir

\begin{tabular}{llrr}
\multicolumn{2}{c}{ Penggilingan } & melakukan & proses \\
penjemuran & gabah, & perontokan & dan \\
penggilinggan & sehingga & diperoleh & beras.
\end{tabular} Penggilingan di setiap kelurahan merupakan pengusaha yang memiliki modal dan sarana transportasi serta gudang penyimpanan. Beras yang telah diproduksi oleh penggilingan, pedagang besar yang menjadi mitranya yaitu Bapak As (Motoboi Kecil), Bapak Muhardi (Pobundayan) dan Bapak Steven (Poyowa Besar I). Kegiatan distribusi dari penggilingan ke pedagang beras bergantung pada kesepakatan yang telah direncanakan. Ada kalanya pengiriman dilakukan oleh penggilingan sampai ke pedagang beras melalui proses transportasi kendaraan yang dimiliki oleh penggilingan sendiri dengan menggunakan biaya sewa kendaraan sesuai dengan tempat tujuan dengan rata-rata sebesar Rp. 200.000 - 
300.000. Ada juga pedagang besar/pedagang pengecer maupun konsumen akhir datang langsung ke penggilingan untuk melakukan mitra kerja yaitu dari Pasar Serasi Kotamobagu, Toko Berkat Kotamobagu, Pasar Bersehati Manado, Pasar 23 Maret Manado, Pasar Gorontalo dan Pasar Boltim. Pembelian oleh pedagang pengecer dilakukan dengan jumlah yang bervariasi dan dilakukan pengemasan ulang sesuai kebutuhan.

Konsumen merupakan rantai terakhir dari proses distribusi beras. Konsumen biasa membeli dalam jumlah sangat kecil dan memerlukan pengemasan ulang yang bervariasi dan pemisahan kembali atas mutu tertentu. Supermarket/pasar merupakan saluran alternatif bagi masyarakat/konsumen untuk membeli beras secara eceran. Pemasaran di supermarket/pasar dilakukan secara curah maupun kemasan dalam volume tertentu dengan kualitas yang lebih baik. Pedagang pengecer merupakan satu-satunya mata rantai yang berfungsi sebagai lembaga perantara atau pemasar produk beras dari penggilingan ke mata rantai berikutnya. Penggilinggan melakukan kegiatan sortasi, pengemasan kemudian didistribusikan kepada pengecer maupun ke konsumen akhir yang membeli.

\section{Aliran Keuangan}

Aliran keuangan dalam rantai pasok ini berupa uang pembayaran atas produk yang dijual kepada mitranya. Aliran keuangan tersebut terdiri dari komponen biaya serta keuntungan yang diterima oleh setiap mata rantai yang terlibat dan mengalir dari hilir ke hulu dan dapat dijelaskan sebagai berikut :

\section{a. Tingkat petani}

Aliran keuangan yang mengalir adalah sejumlah uang yang harus dibayarkan oleh pihak penggilingan kepada petani padi. Harga pembelian ditentukan setiap waktu atas dasar harga yang terjadi dipasar, yaitu sebesar Rp. 150.000/karung (gabah) dengan per karung berisi $25 \mathrm{~kg}$ (gabah). Penentuan harga disesuaikan dengan kelas mutu beras yang akan dijual setelah beras siap di tempat transaksi dan diangkut. Pembayaran dilakukan oleh penggilingan secara tunai.

\section{b. Tingkat penggilingan padi}

Penggilingan ditingkat kelurahan merupakan pengusaha yang memiliki modal dan sarana transportasi serta gudang penyimpanan stok beras. Penggilingan melakukan pembelian gabah kepada petani yang mempunyai hasil panen dalam jumlah gabah yang besar dan tersebar di beberapa tempat. Biaya yang dikeluarkan oleh penggilingan adalah upah buruh berkisar Rp. 150.000. Modal untuk membeli beras biasanya dari modal sendiri.

\section{c. Tingkat pedagang besar}

Jumlah pedagang besar ditingkat kelurahan tidak banyak dan biasanya merangkap sebagai mitra usaha petani padi diwilayahnya. Biaya pemasaran beras yang dikeluarkan oleh pedagang besar adalah ongkos sewa truk Rp. 300.000 untuk mengangkut dan upah buruh sebesar Rp. 150.000 dan modal yang digunakan untuk membayar beras berasal dari modal sendiri. Pembayaran dilakukan dengan sistem tunai kepada penggilingan.

\section{d. Tingkat pengecer}

Pedagang pengecer adalah para pedagang supermarket, pasar atau pemilik warung yang membuka usahanya di lokasi konsumen. Para pedagang pengecer membeli beras langsung dari penggilingan tetapi ada juga yang melalui pedagang besar untuk dijual lansgung ke konsumen. Biaya yang dikeluarkan oleh pedagang pengecer adalah ongkos angkut dari pasar, upah buruh dan pengemasan ulang. Modal yang digunakan oleh pedagang pengecer adalah modal sendiri dan pembayaran atas beras diperoleh secara tunai dari pembeli/konsumen.

\section{e. Konsumen}

Aliran keuangan ini terjadi karena adanya transaksi pembelian produk beras oleh konsumen kepada penggilingan. Aliran keuangan ini terjadi secara langsung ditempat pembelian dengan sistem pembayaran tunai. 
Rata-rata harga jual sesuai harga pasar sebesar Rp. $12.000 / \mathrm{kg}$

\section{Aliran Informasi}

Dalam rantai pasok beras di Kecamatan Kotamobagu Selatan, aliran informasi menjadi komponen yang penting dalam melancarkan aliran produk/barang dan aliran keuangan. Informasi yang disampaikan melalui proses komunikasi dilakukan untuk menjaga rasa kepercayaan antara setiap anggota rantai pasok beras. Aliran informasi mengalir secara timbal balik dari petani kepada konsumen akhir serta sebaliknya yaitu dapat dijelaskan sebagai berikut :

\section{a. Petani dengan Penggilingan Padi}

Aliran informasi yang terjadi antara petani padi dan penggilingan mengalir dua arah, yaitu informasi yang mengalir dari petani padi kepada penggilingan dan informasi yang mengalir dari penggilingan kepada petani padi. Informasi yang mengalir dari petani kepada penggilingan berupa informasi jumlah gabah yang dihasilkan petani tersebut dan mekanisme transaksi penjualan. Informasi yang mengalir dari penggilingan kepada petani adalah berupa informasi harga. Petani yang menjual hasil panen (gabah) disesuaikan dengan harga pasar yang berlaku. Proses komunikasi atau penyampaian informasi antara petani dan pihak penggilingan dilakukan dengan dua cara, yaitu dengan cara penyampaian informasi secara informasi secara langsung (tatap muka) dan menggunakan bantuan media komunikasi (SMS/Telepon).

\section{b. Penggilingan dengan Pedagang Besar}

Aliran informasi diantara pelaku penggilingan dengan pedagang besar terjadi secara dua arah, yaitu mengalir dari penggilingan kepada pedagang besar dan pedagang besar kepada penggilingan. Bentuk informasi yang mengalir dari penggilingan kepada pedagang besar yaitu informasi jumlah beras yang diproduksi, harga jual, jenis beras dan perkiraan waktu untuk sampai ke tangan pembeli. Informasi yang mengalir dari pedagang besar kepada penggilingan berupa jumlah permintaan beras, harga jual dan kritik serta saran dari konsumen.

\section{c. Pedagang Besar dan Pedagang Pengecer}

Aliran informasi antara pedagang besar dengan pedagang pengecer mengalir secara dua arah, yaitu informasi yang mengalir dari pedagang besar kepada pengecer maupun sebaliknya. Informasi yang mengalir dari pedagang besar kepada pengecer berupa jumlah dan jenis beras yang akan didistribusikan serta informasi kapan waktu pengiriman beras tersebut. Sebaliknya informasi dari pengecer kepada pedagang besar berupa informasi tentang harga beli beras sesuai dengan harga pasar yang berlaku.

\section{d. Pedagang Pengecer dan Konsumen Akhir}

Aliran informasi antara pengecer dan konsumen akhir atau pelanggan merupakan arus informasi yang masuk ataupun keluar berupa harga jual beras, jenis beras yang dijual dan kualitas beras, sedangkan informasi berupa jumlah kebutuhan atau konsumsi beras berasal dari konsumen. pertukaran informasi terjadi secara langsung saat transaksi berlangsung.

\section{KESIMPULAN DAN SARAN}

\section{Kesimpulan}

Manajemen rantai pasok beras di Kecamatan Kotamobagu Selatan dimulai dari petani berupa gabah kemudian didistribusikan ke penggilingan padi. Aktivitas pengeringan, penggilingan dan pengemasan dilakukan oleh penggilingan padi dan selanjutnya dijual ke pedagang besar dan pedagang pengecer maupun langsung ke konsumen akhir dalam bentuk beras. Harga jual beras sesuai dengan harga pasar yang berlaku. Proses aktivitas dalam penerapan manajemen rantai pasok yang terjadi di setiap anggota rantai pasok beras di Kecamatan Kotamobagu Selatan merupakan aktivitas yang di mulai dari kerjasama antara petani dan pihak penggilingan berupa bantuan pinjaman modal untuk biaya usahatani padi sawah. Setelah panen, petani akan mengembalikan bantuan pinjaman modal tersebut kepada pihak 
penggilingan berupa gabah yang dihasilkan. Tujuan dari manajemen rantai pasok adalah untuk memenuhi permintaan konsumen secara efektif dan efisien baik dari sisi biaya, waktu dan proses.

\section{Saran}

Sebaiknya dengan adanya penerapan manajemen rantai pasok di Kecamatan Kotamobagu Selatan secara konsisten dan berkesinambungan diharapkan terjadi peningkatan produktivitas, efisiensi usaha dan efektifitas distribusi sehingga dapat memenuhi sekaligus memuaskan kebutuhan konsumen dalam hal aliran produk/barang, aliran keuangan dan informasi. Dengan demikian, pemahaman yang utuh tentang manajemen rantai pasok secara mutlak diperlukan oleh seluruh pelaku rantai pasok di Kecamatan Kotamobagu Selatan sehingga dapat meningkatkan daya saing dan efisiensi dan tiap-tiap pelaku rantai pasok mendapatkan keuntungan dan kesejahteraan yang meningkat. Sejalan dengan itu, keberhasilan membangun manajemen rantai pasok secara berkelanjutan sangat ditentukan oleh komitmen dari setiap pelaku rantai pasok terhadap aturan yang telah disepakati.

\section{DAFTAR PUSTAKA}

Anggraeni, W., 2009. Pengukuran Kinerja Pengelolaan Rantai Pasokan Pada PT.Crown Closures Indonesia (jurnal). Fakultas Teknologi Industri Universitas Gunadarma. Diakses tanggal 10 April 2016.

Anonim. 2017. Dinas Pertanian Kota Kotamobagu. 2015. Luas Lahan Padi Sawah Tahun 2015.

Hadiguna, A. H., 2007. Alokasi Pasokan Berdasarkan Produk Unggulan Untuk Rantai Pasok Sayur Segar. Jurnal Teknik Industri. Vol. 9, No.2. Jurnalindustri.petra.ac.id. diakses tanggal 19 April 2016.
Hamid, N., 2011. Analisis Rantai Pasokan Pada Industri Kacang Goyang di Kotamobagu (Skripsi). Fakultas Pertanian Universitas Sam Ratulangi. Diakses tanggal 7 April 2016.

Iskandar, J. N., 2011. Penentuan Harga Pokok Beras di Kecamatan Kotamobagu Timur Kota Kotamobagu. Fakultas Pertanian Universitas Sam Ratulangi (Skripsi). Diakses tanggal 12 Oktober 2016.

Isnanto, Q., 2009. Analisis Pengelolaan Rantai Pasok Pada PT.PJB Unit Pembangkitan Muara Karang (jurnal). Universitas Gunadarma. Diakses tanggal 3 Maret 2016.

Lokollo, E., 2012. Bunga Rampai: Rantai Pasok Komoditas Pertanian Indonesia. Bogor: IPB Press.

Marimin, dan Maghfiroh, N., 2010. Aplikasi Teknik Pengambilan Keputusan dalam Manajemen Rantai Pasok. Bogor: IPB Press.

Nadhwatunnaja, N., 2008. Analisis Pendapatan Usahatani dan Faktor-Faktor Yang Mempengaruhi Produksi Paprika Hidroponik di Desa Pasir Langu, Kecamatan Cisarua, Kabupaten Bandung. Jurnal Manajemen Agribisnis: IPB. Diakses tanggal 19 September 2016.

Ridwan. 2009. Peningkatan Produktivitas Padi Sawah dengan Perbaikan Teknologi Budidaya. Akta Agrosia Vol. 12 No. 2. Universitas Teknologi Pertanian Sumatera Barat. Diakses tanggal 3 Oktober 2016.

Salsabilla, S. M., 2014. Analisis Manajemen Rantai Pasok (Supply Chain Manajemen) Padi Pasca Panen di Pabrik Beras Sukoreno Makmur Kecamatan Kalisat (jurnal). Universitas Jember. Diakses tanggal 15 September 2016. 
Saragih, B., 2000. Prospek Agribisnis dan Evaluasi Pembangunan Pertanian (jurnal). Fakultas Pertanian: IPB. Diakses tanggal 28 September 2016.

Sihombing, D. T., 2015. Analisis Nilai Tambah Rantai Pasok Beras di Desa Tatengesan Kecamatan Pusomaen Kabupaten Minahasan Tenggara. Jurnal EMBA, Vol. 3, No. 2, ejournal.unsrat.ac.id, diakses tanggal 7 April 2016.

Soekartawi. 2010. Analisis Usaha Tani. Universitas Indonesia-Press, Jakarta.

Suparta, N., 2005. Dampak Pengembangan Agribisnis Pada Subak Terhadap Pendapatan Rumah Tangga Petani Kecamatan Marga, Kabupaten Tabanan. Jurnal Manajemen Agribisnis, Vol. 2, No. 1. Universitas Udayana. Diakses tanggal 2 Oktober 2016.
Taufik, M., 2012. Strategi Pengembangan Agribisnis Sayuran di Sulawesi Selatan. Jurnal Litbang Pertanian. Diakses tanggal 28 September 2016.

Yanti, I. N., 2015. Upaya Peningkatan Produksi Padi Sawah Varietas IR 64 Melalui Sistem Tanam Jajar Legowo 4:1 di Kabupaten Bantul Yogyakarta (jurnal). Universitas Politeknik Pertanian Negeri Payahkumbuh. Diakses tanggal 3 Oktober 2016. 